DOI: $10.2478 / \mathrm{v} 10025-010-0026-5$

JOURNAL OF WATER

AND LAND DEVELOPMENT

J. Water Land Dev. No. 13a, 2009: 161-175

\title{
Landscape alteration in view of soil protection from water erosion - an example of the Mielnica watershed
}

\author{
Romuald ŻMUDA ${ }^{1)}$, Szymon SZEWRAŃSKI ${ }^{2)}$, Tomasz KOWALCZYK ${ }^{1)}$, \\ Eukasz SZARAWARSKI ${ }^{1}$, Michat KURIATA ${ }^{1)}$
}

\footnotetext{
1) Wrocław University of Environmental and Live Sciences, Institute of Environmental Development and Protection, pl. Grunwaldzki 24, 50-363 Wrocław, Poland, e-mail: romuald.zmuda@up.wroc.pl

${ }^{2)}$ Wrocław University of Environmental and Live Sciences, Department of Rural Landscape Planning and Development, ul. Grunwaldzka 53, 50-357 Wrocław, Poland
}

\begin{abstract}
The paper pertains to landscape management in eroded areas. Erosion processes, especially water erosion of soils, change the existing landscapes and make them less attractive or even hostile to people. Such situation calls for protective actions e.g. an appropriate management of agricultural landscape to minimise negative consequences of such phenomena. The paper presents a concept of counter-erosion measures to be implemented in the Trzebnickie Hills and comments their effect on the landscape. The concept was applied to an agricultural watershed of the Mielnica River. Particular attention was paid to visual aspect of this landscape and to functioning of its elements. Changes in the landscape were visualised and set up with the present status of the watershed.
\end{abstract}

Key words: landscape architecture, phytoreclamations, water erosion of soils

\section{INTRODUCTION}

Appropriate protection of agricultural soils from water erosion should involve the improvement of landscape values and the maintenance of natural phenomena. Up to date land management in eroded areas has developed a set of measures that limited or minimised the effects of soil degradation by water erosion. Phytoreclamation is usually used in areas most susceptible to water erosion. This measure additionally improves the productive capabilities of soils in adjacent areas. Forests and thickets are seen as most effective in soil protection from erosion and as an extremely valuable landscape element. They posses unique, specific and characteristic aesthetic values and play important role in landscape composition (ŻARSKA, 2005). Landscape management should consider both visible elements of land relief and not always visible relations between these elements (BOGDANOWSKI et al., 
1981). Optimised landscape ecological structure positively affects soil protection which is the more effective the larger are biologically active areas and the better is their inter-connectivity.

In areas of very good soils and devoid of forests the only alternative in shaping the aesthetics of agricultural lands are woodlots. They protect and form rich structure of agricultural landscape (Photo 1) and increase its biodiversity (KARG and BERNACKI, 2008). Apart from scientifically proven effect on the decrease of soil erosion the woodlots play a role of ecological corridors. They should form a net among habitat islands (e.g. forest complexes) to strengthen ecological structure of agricultural landscape (PUCHNIARSKI, 2000).

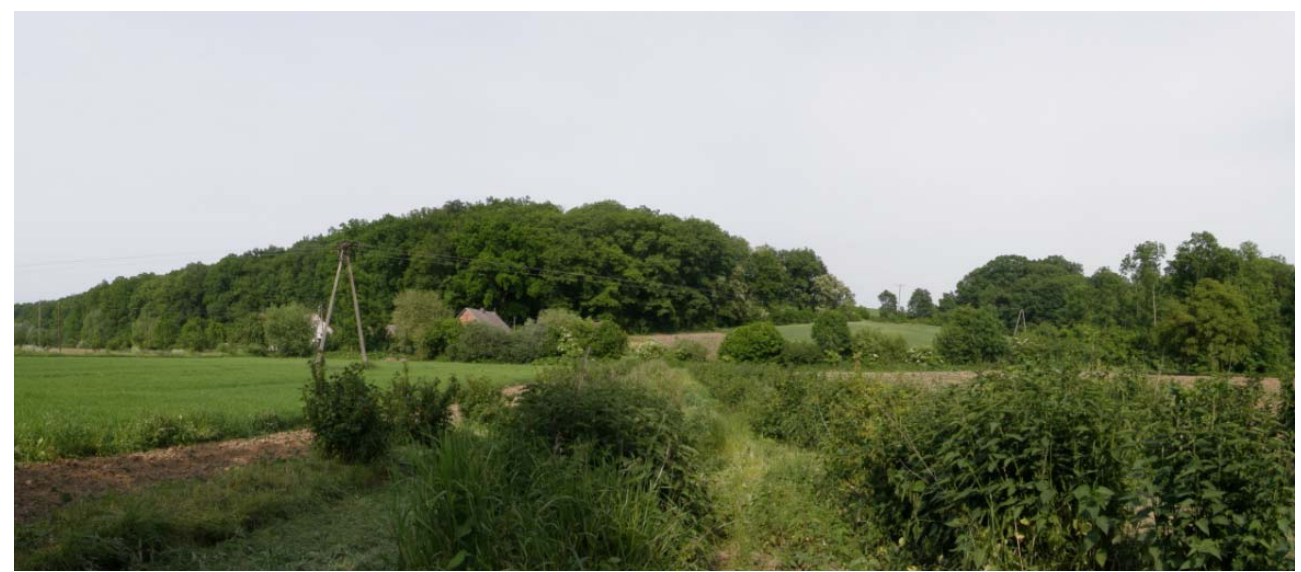

Photo 1. Fragment of agricultural landscape of the Trzebnickie Hills of rich habitat structure - watershed of the Mielnica, May 2008

Eroded areas require specific arrangement of shelterbelts depending largely on slope direction. The only proper direction is planting shelterbelts across the slope or in surface clusters in particularly threatened areas. Such shelterbelt should play a role of biogeochemical barriers which hamper surface runoff and direct it under ground, retain soil material carried by water and change chemical composition of the outflow beneath shelterbelts (MIODUSZEWSKI, 1995; 2003). The efficiency of shelterbelt depends on the ratio of its width to the width of fields above it. The recommended ratio is 1:5(10) (ZIEMNICKI, 1968; WĘGOREK, 1997).

\section{MATERIALS AND METHODS}

Studied watershed of the Mielnica is situated on southern hillsides of the Trzebnickie Hills in the Silesian voivodship, Trzebnica county (Fig. 1). It covers 


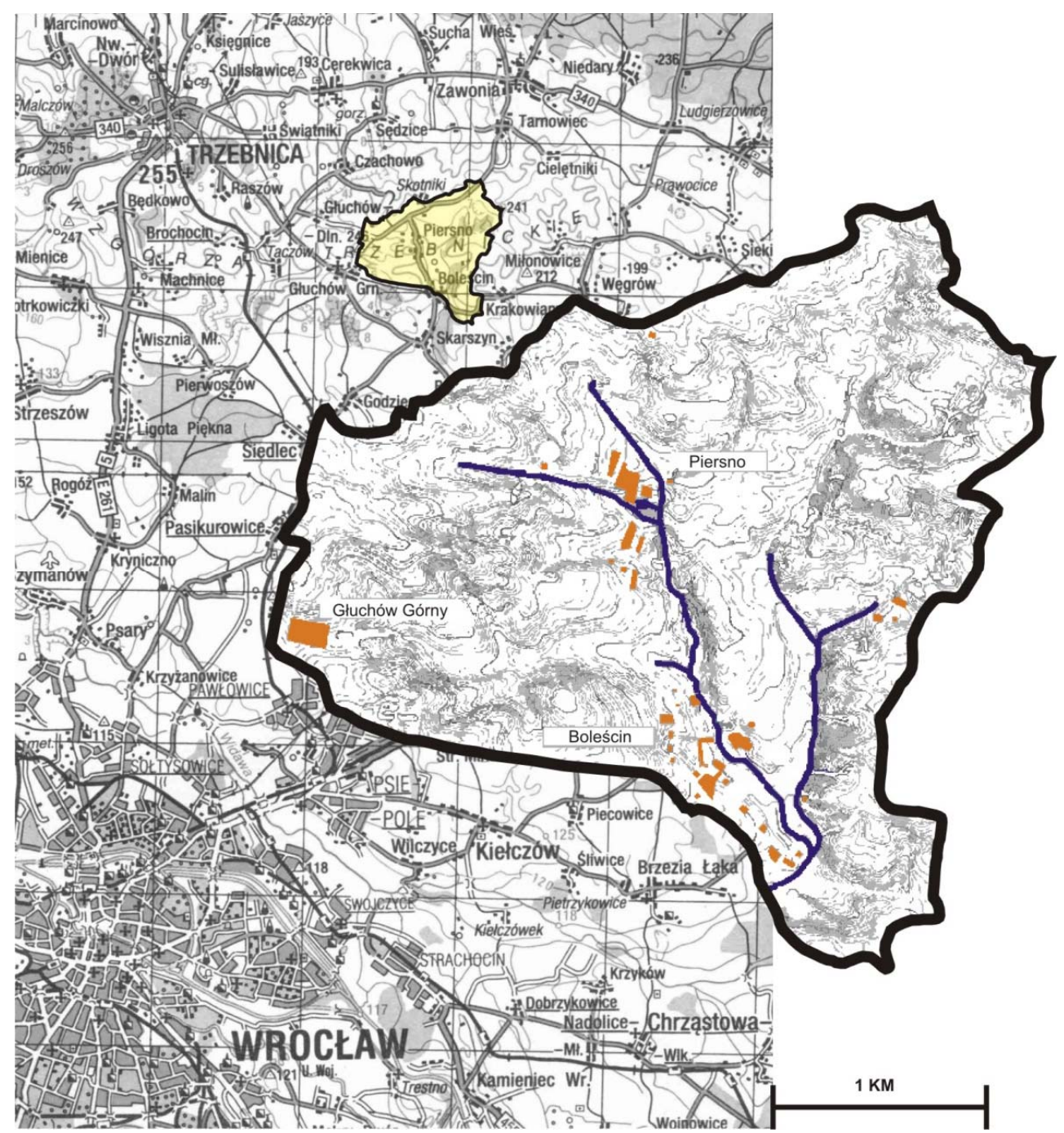

Fig. 1. An overview map of the Mielnica watershed and its location

an area of several villages and the closest town is Trzebnica situated $9 \mathrm{~km}$ to the north-west. The distance from Wrocław is c. $20 \mathrm{~km}$. Watershed area is 711.4 ha.

The Trzebnickie Hills acc. to Romer (cited after BAC et al., 1993) belong to the region of submountain valleys and lowlands. The climate is relatively mild there. It is characterised by shortest winters, longest summers, longest vegetation periods and smaller but favourably distributed rainfalls. The analysis made by BAC (1991) showed that the agro-climate is moderately wet, moderately warm and moderately sunny there. During winter half-years the hills, especially their southern slopes with the watershed in question, are warmer than the rest of the region. 
Consequently different are the periods of thaw and the height of atmospheric precipitation (Atlas klimatycznych..., 1987). The first thaw appears near December the $12^{\text {th }}$ and the last on March the $11^{\text {th }}$. Annual sums of precipitation vary between 650 and $800 \mathrm{~mm}$ and the mean number of days with precipitation (larger than 0.1 $\mathrm{mm}$ ) ranges between 140 and 160 .

Average length of the period with positive temperatures is 290 to 310 days, thermal winter starts at the end of December and lasts until the end of February and the mean annual temperature is c. $8^{\circ} \mathrm{C}$. First autumn frosts are being noted on October the $9^{\text {th }}$ but may happen as soon as September the $14^{\text {th }}$. The last spring frosts are noted around May the $3^{\text {rd }}$ (WISZNIEWSKI and CHELCHOWSKI, 1975).

Spatial distribution of water balances analysed by ROJEK (1987) shows that the region is characterised by a small surplus of atmospheric precipitation of c. 20 $\mathrm{mm}$. In the wintertime (October to March) the excess is c. $100 \mathrm{~mm}$ while in the period between April and September there is a water deficit of 40-60 mm.

Studies carried out in the Mielnica watershed by ŻMUDA (2006) in the years 1983-2004 allow for the conclusion that mean annual temperatures vary between 6.4 and $9.8^{\circ} \mathrm{C}$. Annual sums of atmospheric precipitation range from 463.8 to 762.0 $\mathrm{mm}$ out of which $63 \%$ are the summer rainfalls. Maximum daily sums of precipitation exceeding $12.7 \mathrm{~mm}$, single rains of mean intensity exceeding $6.3 \mathrm{~mm} \cdot \mathrm{h}^{-1}$ and momentary rainfalls of as much as $100 \mathrm{~mm} \cdot \mathrm{h}^{-1}$ are frequent phenomena in this area.

Brown soils are the dominating type $(92.38 \%$ of the watershed area) of soils and loess is the dominating kind there (95.25\%). Grain size structure of these soils varies depending on sampling site. The index of soil susceptibility to outwashing assumes the values from 1.7 to 5.8 being higher on tops of hills, lower at the foot of hills and the lowest - on slopes. Compared with the values determined by various authors in other regions of Poland, soils from the Mielnica watershed are classified as least resistant to outwashing. They are similar to loess soils in the Lublin Upland - the area most threatened by water erosion in the country (REJMAN et al., 1998).

Considering the risk of potential water erosion and the need of counter-erosion protection the catchment should be listed to the first degree of urgency of protective measures since $50.3 \%$ of its area falls within class 3 or higher (Tab. 1) (JÓZEFACIUK and JÓZEFACIUK, 1996). Agricultural land use with the dominance of arable lands ploughed along the slope (Photo 2) makes the actual threat of highest classes markedly increase (up to $84.6 \%$ of area - Tab. 1) (ŻMUDA et al., 2001; 2005).

The Trzebnickie Hills have great natural values important for landscape architecture. Geobotanically, they are situated in Brandenburg-Wielkopolska Division, South-wielkopolska-Łużyce Country, Eastern Sub-country (MATUSZKIEWICZ, 2007), Trzebnica Region (Atlas Śląska..., 1997). The area is exceptional due to the presence of many representatives of mountain, xerothermic and peatland flora and of mane nearly extinct segetal species associated with already abandoned tradi- 
Table 1. Areas of potential and actual water erosion in the Mielnica watershed (ŻMUDA, 2006)

\begin{tabular}{l|c|c|c|c}
\hline \multirow{2}{*}{\multicolumn{1}{c}{ Intensity }} & \multicolumn{4}{c}{ Threatened areas } \\
\cline { 2 - 5 } & \multicolumn{2}{c}{ potential erosion } & \multicolumn{2}{c}{ actual erosion } \\
\cline { 2 - 5 } & ha & $\%$ & ha & $\%$ \\
\hline Weak erosion (1) & 119.4 & 16.8 & 6.4 & 0.9 \\
Moderate erosion (2) & 194.9 & 27.4 & 66.9 & 9.4 \\
Medium erosion (3) & 171.4 & 24.1 & 313.7 & 44.1 \\
Strong erosion (4) & 128.8 & 18.1 & 253.2 & 35.6 \\
Very strong erosion (5) & 60.5 & 8.5 & 34.8 & 4.9 \\
Ravine erosion & 36.4 & 5.1 & 36.4 & 5.1 \\
Total: & $\mathbf{7 1 1 . 4}$ & $\mathbf{1 0 0 . 0}$ & $\mathbf{7 1 1 . 4}$ & $\mathbf{1 0 0 . 0}$ \\
\hline
\end{tabular}

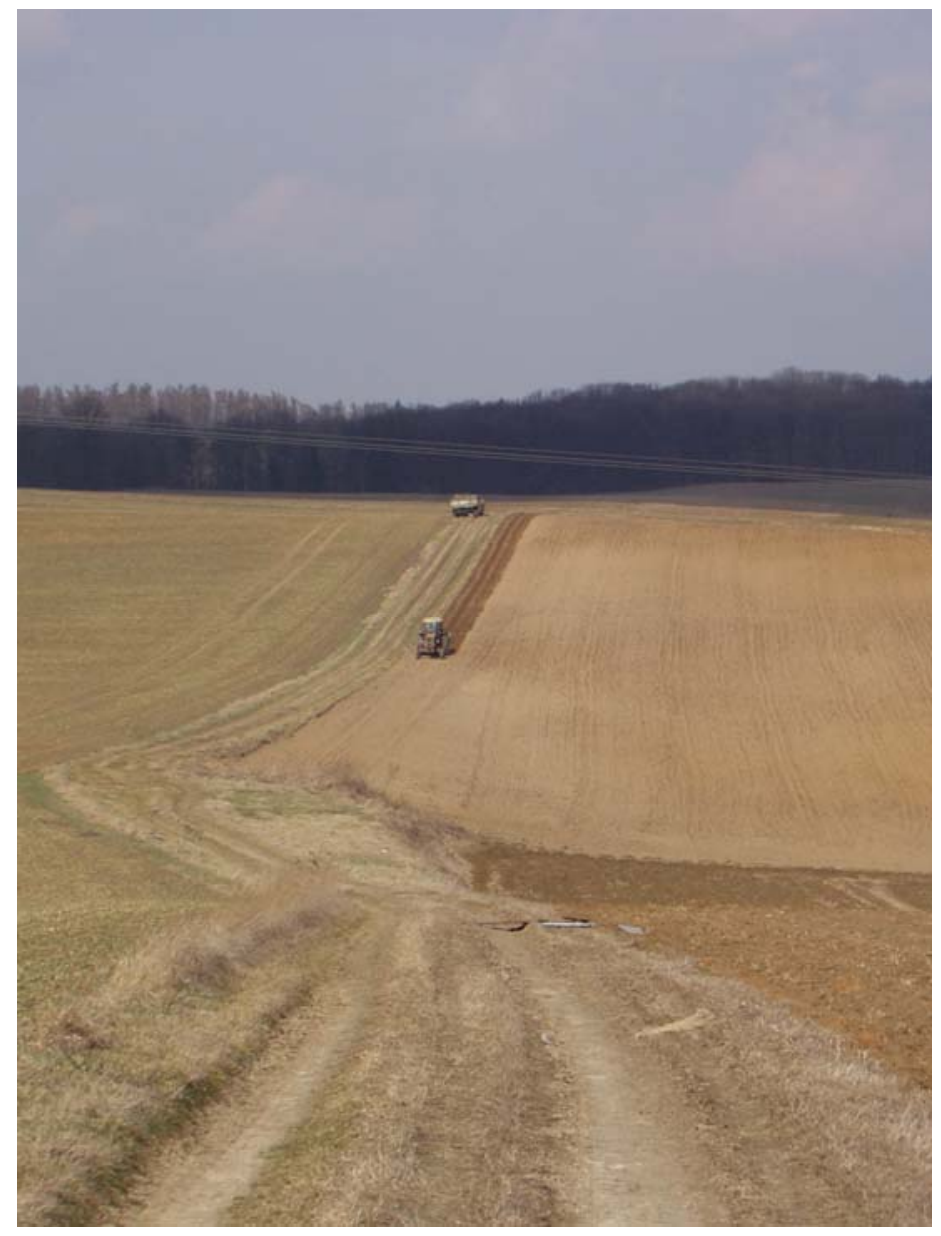

Photo 2. Wrong direction of ploughing and other agro-technical measures common on the Trzebnickie Hills - the Mielnica watershed March 2003 
tional forms of farming (ANIOŁ-KWIATKOWSKA, 2003). The remnants of natural and semi-natural phytocoenoses survived mainly on steep sides of valleys and ravines, on escarps and in local depressions. Sides of valleys are mainly covered by various forest communities. On escarps and walls of excavations one may find many xerothermic and thermophilous species. Seminatural fresh and wet meadows are usually associated with river valleys. Most wet and boggy areas are occupied by rush communities. Stream valleys usually covered by fragments of diverse deciduous forests are the most biologically valuable objects. One of such forest fragments in the lower course of the Mielnica River, outside of the studied watershed, is legally protected as a nature reserve "Beech forest in Skarszyn" (PENDER and RYBAŁTOWSKA, 1995).

Most beautiful fragment of this formation of great biological and landscape values spreads between Trzebnica and Oborniki Śląskie. There are many variously developed ravines, valleys and gulches that evidence erosion processes taking place there. Mean density of ravine network in the $276 \mathrm{~km}^{2}$ area of the Trzebnickie Hills is $0.184 \mathrm{~km} \cdot \mathrm{km}^{-2}$. The ravines cover $43 \%$ of this area. Most cut by ravines are southern hillsides near Skarszyn where the density reaches up to $5 \mathrm{~km} \cdot \mathrm{km}^{-2}$ (JARY and KIDA, 2002). The density of ravine network is comparable with respective values for Roztocze Gorajskie and Nałęczów Plateau - considered the areas most fragmented by ravines and loess covered in Poland (BURACZYŃSKI, 1990). However, strong ravine erosion occurs there on only $1.1 \%$ of area; most frequent is moderate erosion (27.9\% of area). Studies of loess areas in Lower Silesia carried out by the Wrocław University indicate that now the phenomena of surface water erosion dominate there in contrast with loess areas in central and eastern Poland (CEGLA, 1972; JARY, 1991; KIDA, 1996).

The presence of valuable and rare plant communities there is an evidence of great biological and landscape values of the Mielnica watershed. Xeric sand calcareous grassland Koelerion glaucae with sites of rare grass species might be an example. Other endangered and rare habitats include Tilio-Acerion ravine forest near Głuchów Górny or Galio-Carpinetum oak-hornbeam forest and Lazulo-Fagetum beech forest near Boleścin (BOBROWICZ and KONIECZNY, 2004).

The concept of protection of the Mielnica watershed from water erosion was based on the analysis of ecological and landscape conditions, local physiography and farming conditions. The main principles of landscape management in the context of nature protection adopted in this paper were:

- creation of natural systems (protected areas) together with ecological corridors connecting similar areas,

- creation and strengthening ecological structure of the landscape involving natural systems composed of various, mainly natural structures (protection of the existing and well preserved ecosystems and restoration of destroyed natural elements), 
- improvement of ecological connectivity between biologically valuable areas,

- optimisation of ecological structure through protection of the existing large natural ecosystems, maintenance and creation of mosaic landscapes and enrichment of ecological structure of areas under heavy human impact,

- protection of large forest complexes rich in species and plant communities particularly visible in large compact forests. New forest plantings were concentrated near existing forests and small forest complexes were included in the system of ecological corridors,

- protection of natural ecotones through the introduction of buffer zones around biologically valuable areas and management of adjacent areas in a way to mitigate the negative effect of surrounding and to diminish isolation of habitat islands,

- non-disturbance of natural phytocoenoses, ecosystems and ecological stability by human actions (e. g. forest logging)

The principles listed above were supplemented with repair actions of general and detailed character. General actions included: common implementation of the principles of good agricultural practices, implementation of and adherence to environmental protection regulations, protection and maintenance of soil potential, counteraction of hydrologic degradation of streams and restriction of surface and groundwater pollution. Detailed actions included: absolute liquidation of illegal hydrotechnical built-up, liquidation of point sources of surface water pollution, changing the direction of ploughing and other agro-technical measures, introduction of buffer zones, woodlots, shrubs, orchards and vineyards and formation of an additional element of habitat protection in a form of water hole and a bicycle lane as a recreational object.

All this forms a set of agro-environmental measures facilitating environmental protection of agricultural watershed and composing into the so-called process of rural renewal. Proposed changes were illustrated in maps elaborated in the GIS system with the use of CORINE database of land cover and photographic documentation of present status and visualisation of proposed changes. Due to limited volume of this paper illustration of planning results were restricted to photos of some locations.

\section{RESULTS OF CONCEPTUAL PLANS (COUNTER-EROSION MEASURES AND LANDSCAPE CHANGES)}

Proposals of agro-environmental actions adjusted to local conditions were worked out according to the Code of Good Agricultural Practices. The actions agree with European standards of sustainable farming and environmental friendly agricultural production. When planning this model scenario we based on Polish legal acts, directives of the European Union and recommendations of HELCOM 
adopting them to local conditions and specific character of area in question and on results of analyses made with GIS technique.

Proposed changes in agricultural production pertain to: farming systems, cropland structure, crop rotation, fertilisation (below $170 \mathrm{~kg} \mathrm{~N} \cdot \mathrm{ha}^{-1}$ and $300 \mathrm{~kg}$ $\mathrm{NPK} \cdot \mathrm{ha}^{-1}$ as the optimum level) and protection from pollution of running waters through the introduction of buffer phytocoenoses.

Because studied watershed undergoes strong soil degradation, particular attention was paid to counter-erosion systems and actions. The proposals included:

- permanent afforestation of grounds on hillsides inclined more than $15 \%$,

- permanent grassland management and orchards on hillsides inclined 10-15\%,

- special way of soil cultivation on hillsides of an inclination up to $10 \%$, particularly on long slopes despite their weaker exposition to water erosion,

- counter-erosion management of rainfall runoff and protection of rural roads,

- counter-erosion crop rotation with plants protecting soil (legumes or their mixtures with grasses and winter crops that form dense plant cover already in autumn),

- soil protecting aftercrops and strip cultivation $10-15 \mathrm{~m}$ wide with alternating tuber crops, cereals (maize) and protective legumes and grasses, belts of protective vegetation (winter cereals and lupine),

- soil cultivation across the slope, ploughing with ridge turnover and limitation of these measures to necessary minimum,

- introduction of crops without ploughing on slopes (using cultivators with wide shanks or strip-till techniques for forecrop cultivation),

- introduction of deep cultivating as an additional counter-erosion measure to increase soil water capacity and to facilitate water infiltration to deeper soil layers.

All proposed changes, apart from minimising water erosion of soils, exert an effect on landscape. The need of protecting the Trzebnickie Hills, particularly their southern side, from erosion was described by ŻMUDA et al. (2005) using the Mielnica watershed as an example. Results of these analyses indicate that phytoreclamation should be performed on 5\% of the watershed area. Phytoreclamations are particularly important since they enrich the landscape structure and increase its biodiversity. According to legal regulations, afforestation means planting trees on an area larger than 0.1 ha. In practice, however, larger plantings other than commercial forests (and such can be found in the Mielnica watershed) might be considered woodlots (PUCHNIARSKI, 2000). An important element of the concept is just to introduce midfield woodlots and shelterbelts minimum $5 \mathrm{~m}$ wide running along the contour lines and along prevailing wind directions. Woodlots play a role of ecological corridors, decrease the distance between habitat islands and positively affect all natural and seminatural biotic systems of the watershed. Such corridors exert positive effect on entomofauna which in turn is favourable to agricultural crops (ORŁOWSKI, 2003). 
Afforestation was planned on part of hill tops, on hillsides and along the river. Due to the proceeding loess erosion it was decided to exclude from agricultural use almost all fragments of the area inclined more than $15 \%$ and most areas of inclinations higher than $10 \%$. New planting of maple, oak, larch and ash trees were planned (Photo 3). Single and group transfers will include: ash, linden, birch, aspen, oak, sycamore maple, alder, pine, poplar and hornbeam. The bird cherry, willow, European elder, linden and aspen were selected as plants of the second floor. Ivy, raspberry, blackberry, jewelweed, the sallow thorn, nettle, hop, reed and hawthorn will grow in the undergrowth. Two forecrops are proposed to be used before each tree planting - e.g. of legumes and their mixtures with lupine and then of willow, hazel nut, dog rose and pear. Forest areas have to be developed in the river zone to form an ecological corridor together with existing forests and orchards, planned buffer zones and grasslands (Photo 4). Apart from trees already growing in the watercourse zone, additionally planned forests will be of beech with sycamore maple, larch, oak and European elder, and of ash trees with spruce, aspen, willow, European elder and hazel nut. The undergrowth will consist of the sallow
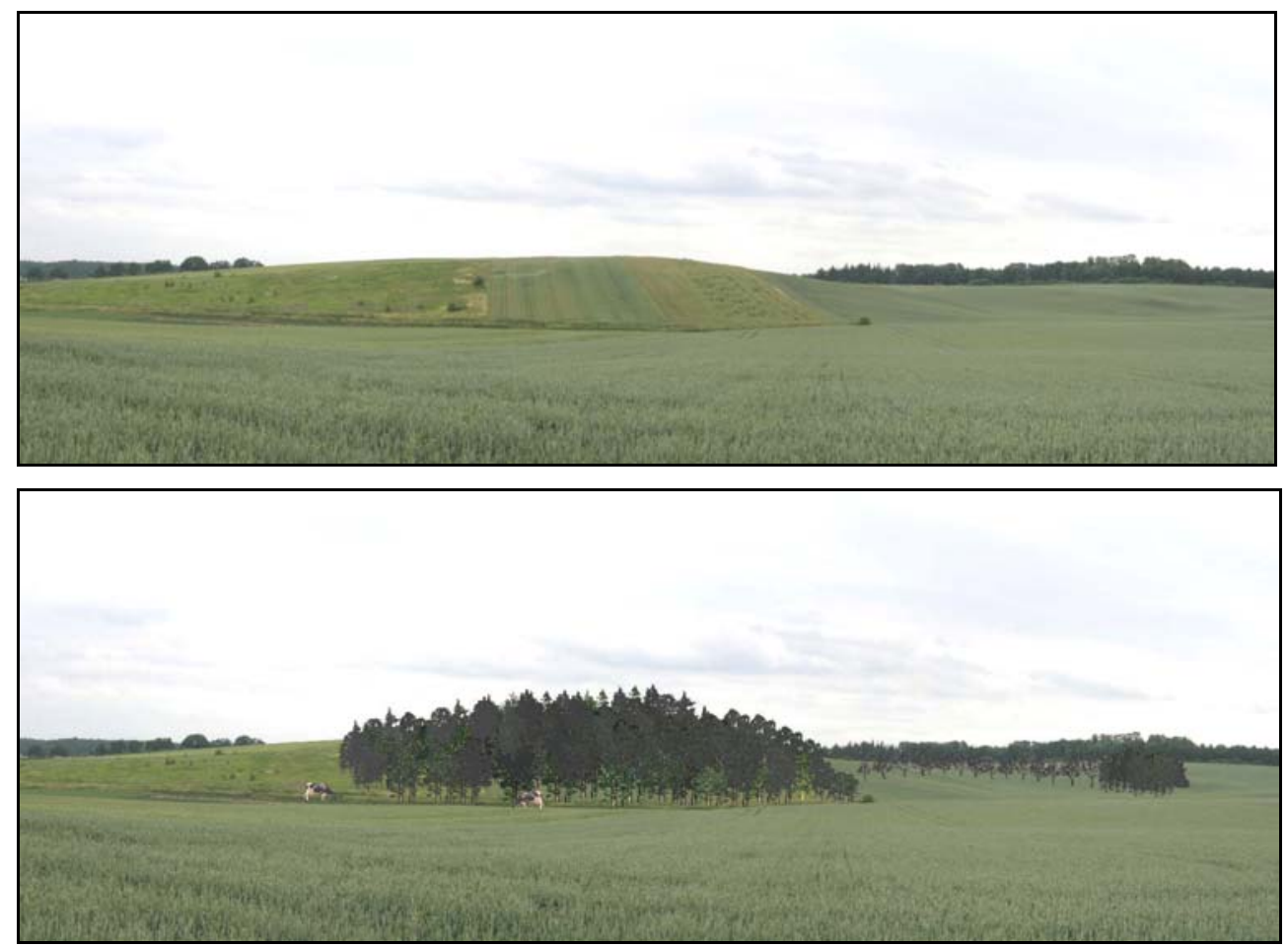

Photo 3. Landscape visualisation after changes - tree planting on a steep hillside 

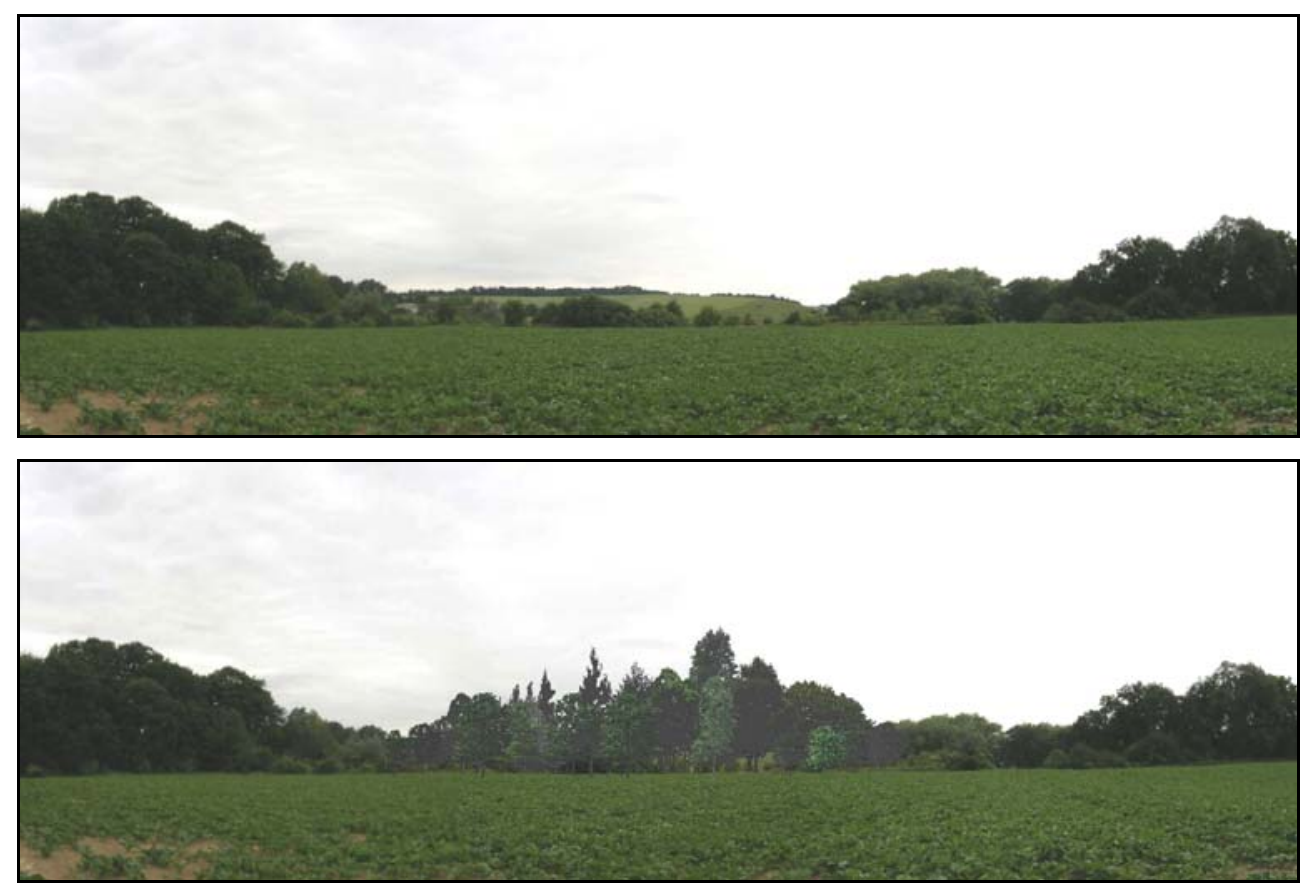

Photo 4. The area near the Mielnica River intended for afforestation and planned to become a buffer zone

thorn, blackberry, raspberry, ivy, jewelweed, nettle and sedges. Plantings of similar species composition will also appear along periodical watercourses.

It was proposed to introduce buffer strips 25 and $18 \mathrm{~m}$ wide. Zones of a width of 4, 6 and $15 \mathrm{~m}$ and 3,5 and $10 \mathrm{~m}$, respectively, will be distinguished along the watercourses. Species composition in particular zones will be as follows:

- zone 1 - the common hawthorn, common juniper, European elder and dog rose,

- zone 2 - the hazel nut, plum, cherry plum, bird cherry and Cornelian cherry,

- zone 3 - tall trees like oak, beech and hornbeam.

Shrubs play also the role of buffer strips. Soil protecting formations were also planned on very steep escarps that appear between inappropriately cultivated fields. They are composed of shrubs (common privet, raspberry, common spindle tree, and dog rose) and grasses: the oat-grass, rye-grass and sheep fescue. Buffer strips will be supplemented by sowing grass on roadsides. The oat-grass, perennial ryegrass, sheep fescue, meadow fescue, meadow foxtail in more wet places and timothy-grass are recommended in that case.

Planting of midfield woodlots was planned in a form of landscape character (Photo 5) and as openwork belts $5 \mathrm{~m}$ wide (right side of Photo 3). Shelterbelts protect soils from westerly winds prevailing in the watershed. Species to be planted include: the small-leaved lime tree, maple, wild cherry, wild elder, and dog rose. 

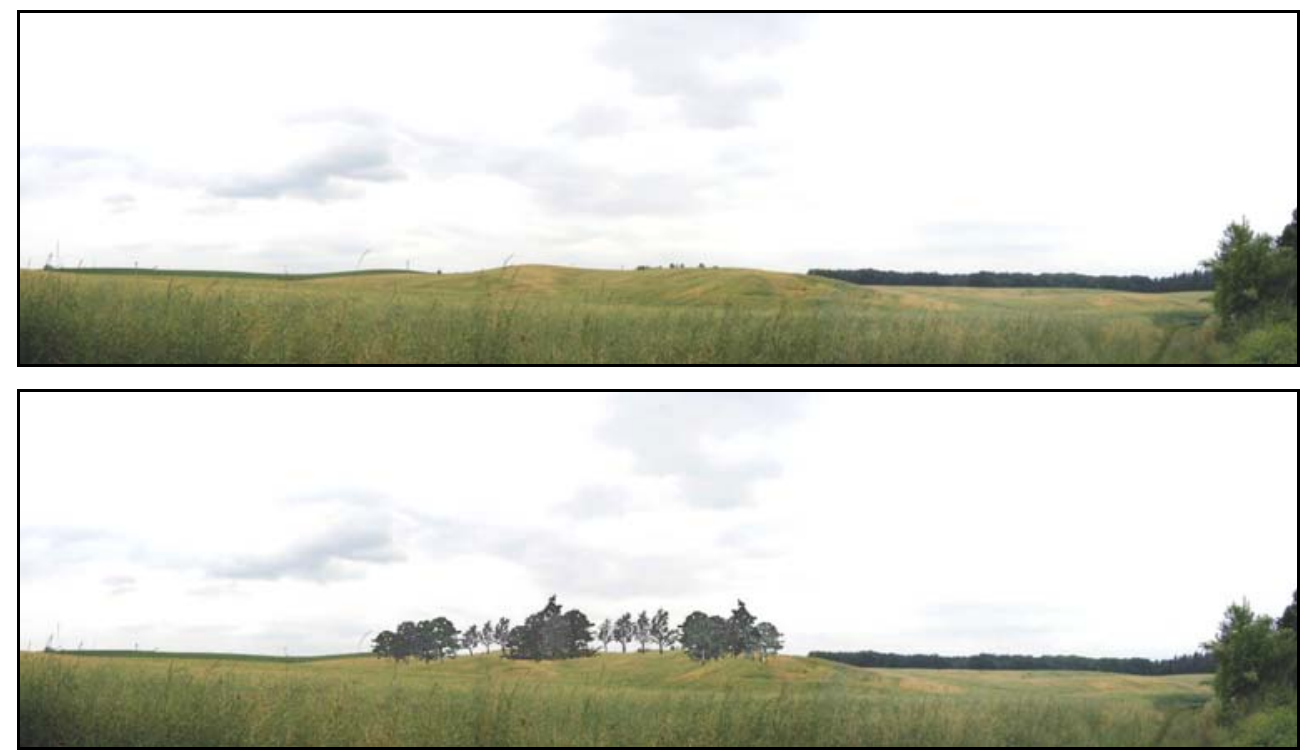

Photo 5. Introduction of midfield woodlots of landscape character into unattractive, uniform and exposed to erosion fragment of the Mielnica watershed

Sowing grasslands and planting orchards on part of arable lands will supplement counter-erosion management. Grasses are planned to be sown on hillsides of an inclination of $10-15 \%$ and to supplement permanent woodlots and shrubs. The red fescue, brome grass, cocksfoot, perennial rye-grass, white melilot, sickle and black medics and meadow clover are proposed for sowing. Due to high productive potential of soils it was decided to introduce orchards (as a substitute for woodlots) on hillsides of $10-15 \%$ inclination and southern exposition. Proposed tree species have to be: cherry, apple, peach tree and currant. It is also possible to introduce vineyards because of favourable thermal conditions of the region manifesting themselves by annual sums of mean daily temperatures above $10^{\circ} \mathrm{C}$. Planting should be performed across slopes. From among possible varieties, Aurora, Festiwalnyj, Rakisz (for white wines) and Iliczewskij Rannij, Rondo, Caskade (for red wines) might be considered as the strains of vine plants resistant to pests and frost.

The need of modernisation of rural roads in the watershed was also considered in the proposal of counter-erosion measures. Proposed system solutions were discussed in WAWER et al. (2008). During field survey special attention was paid to marked ecological degradation of the Mielnica channel and the whole valley. The watercourse is heavily silted and polluted with wastes. Illegal delivery of waste waters was observed. "Wild" regulation and technical built-up of the channel can sporadically be found. These irregularities should definitely be removed. The problem and proposals of necessary restoration measures to reinstate the attractiveness and functionality of rural area are described in SZEWRAŃSKI et al. (2006). 
There are practical recommendations in Poland concerning both management and measures with respect to erosion risk. Long studies allow for modelling the intensity of soil erosion for selected management variants of particular hillsides or the whole watershed. The models are directly oriented to soil protection and indirectly - on the protection of surface waters. There are also methods that enable estimate present and planned value of landscape architecture. At the contact of the two approaches to space management a common element should appear that would combine often discordant interests of farmers and landscape architects to serve environmental protection and aesthetics.

\section{SUMMARY AND CONCLUSIONS}

Analysed fragment of the Trzebnickie Hills, as the rest of area, has quite diverse relief. There are many ravines and moraine hills of high inclination. Fertile loess soils (particularly abundant on southern slopes of the hills) are the reason of agricultural development there. However, specific physiographic and pedologic conditions make the area subject to water erosion of soils and agriculture faces many problems. Agricultural activity should be compromised with the need of environmental protection. One of the possible solutions is appropriately formed agricultural landscape. Agro-environmental programmes that include also landscape aesthetics are the chance for farmers and for environment.

The area of the Trzebnica commune with prevailing part of the Mielnica watershed was included in the Country Agro-environmental Programme in the priority zone "The Odra River valley" (02B) which should be elaborated till the year 2014 (BOBROWICZ and KONIECZNY, 2004). It is a chance for the Trzebnickie Hills which should be used when planning definite actions and only then the agricultural spaces under a heavy human impact may assume nature and user friendly aesthetic appearance.

Presented concept of counter-erosion actions in the small agricultural watershed of the Trzebnickie Hills indicates the direction often neglected in such works. It points to a need of analysing changes in agricultural landscape made by the introduction of new architectonic elements into its structure. The introduction of woodlots and shrubs increases ecological stability of the area and turns unattractive and uniform agricultural landscape into the one of rich ecological structure.

Experience gathered during this study and the results of studies in the Mielnica watershed on various aspects of water erosion of soils allow to formulate the following conclusions:

1. An example of the Mielnica watershed representing areas drained by waters from the Trzebnickie Hills shows that soils of these areas are threatened by water erosion and that there is a need to apply complex protective measures. The hills 
should be protected against erosion which is always associated with landscape transformation.

2. Proposed actions will effect in alteration of the landscape structure to mitigate unfavourable and destructive water impact on soils. Proposed changes will include modification of the land use structure, transformation of arable lands into grasslands, introduction of new forest complexes and midfield woodlots of protective and landscape character and proper distribution of particular types of land use adjusted to the terrain physiography.

3. Counter-erosion measures planned in this paper are a vision of actions that should contribute to positive changes in the landscape of the Trzebnickie Hills. Biodiversity will increase and stability of natural systems will improve in anthropogenic areas like croplands of the Hills

\section{REFERENCES}

1. AnioŁ-KwiAtKowsKa J., 2003. Zagrożenia flory synantropijnej Dolnego Śląska - problemy wymierania archeofitów. Zagrożone gatunki flory naczyniowej Dolnego Śląska. (A risk to synanthropic flora in Lower Silesia - problems of archeophyte extinction. Endangered species of vascular flora in Lower Silesia). Red. Z. Kącki. Wrocław, UWroc., PTPP „pro Natura”: 151-164.

2. Atlas klimatyczny elementów i zjawisk atmosferycznych szkodliwych dla rolnictwa w Polsce, 1987. (Atlas of climatic elements and atmospheric phenomena harmful for agriculture in Poland). Pr. zb. Red. Cz. Koźmiński, B. Michalska, T. Górski. Puławy, Wydaw. IUNG: 63.

3. Atlas Śląska Dolnego i Opolskiego, 1997. (Atlas of Lower and Opole Silesia). Pr. zbior. Red. W. Pawlak. Wrocław, UWroc.

4. BAC S., 1991. Ocena warunków agroklimatycznych do celów rolnictwa. (The assessment of agroclimatic conditions for agriculture). Acta Univ. Wratisl. Pr. Geogr. Ser. A Geogr. Fiz. 6: 5-17

5. BAC S., KoŹMIŃSKI C., ROJeK M., 1993. Agrometeorologia. (Agro-meteorology). Warszawa, PWN: 252.

6. Bobrowicz G., KonieCZNY K., 2004. Waloryzacja przyrodnicza gminy Trzebnica. (Natural valorisation of the Trzebnica commune). Wrocław, PTPP „pro Natura”: 102.

7. BogdANOWSKi J., ŁuCZYŃSKA-BRUZDA M., NowAK Z., 1981. Architektura krajobrazu. (Landscape architecture). Warszawa, PWN: 246

8. BURACZYŃSKI J., 1990. Rozwój wąwozów na Roztoczu Gorajskim w ostatnim tysiącleciu. (Development of ravines in Roztocze Gorajskie during the last millenium). Ann. UMCS 44/45, Sect. B: 95-104.

9. CegŁa J., 1972. Sedymentacja lessów Polski. (Sedimentation of loess in Poland). Acta Univ. Wratisl. St. Geogr., 168: 71.

10. JARY Z., 1991. Profil utworów lessowych w Trzebnicy koło Wrocławia. W: Podstawowe profile lessów w Polsce. (Profile of loess formations in Trzebnica near Wrocław. In: Basic loess profiles in Poland). Pr. zbior. Red. H. Maruszczak. Lublin, UMCS: 196-200.

11. JARY Z., KIDA J., 2002. Erozja wąwozowa na obszarach lessowych południowo-zachodniej Polski. (Ravine erosion in loess areas of south-western Poland). Zesz. Probl. Post. Nauk Rol. 487: 79-86.

12. JÓzeFACIUK A., JózEFACIUK Cz., 1996. Mechanizm i wskazówki metodyczne badania procesów erozji. (Mechanism and methodical guides to study erosion processes). Bibl. Monit. Środ., Warszawa, Wydaw. PIOŚ: 148.

13. KARG J., BERNACKI Z., 2008. Zadrzewienia śródpolne w krajobrazie rolniczym. Problem erozji gleb w procesie przemian strukturalnych na obszarach wiejskich. (Midfield woodlots in agricultural land- 
scape. Problem of soil erosion in the process of structural changes of rural areas). St. Raporty IUNGPIB, 10, Puławy: 39-57

14. KIDA J., 1996. Niektóre cechy rzeźby lessowej Opolszczyzny. (Some features of loess relief in Opole region). Acta Univ. Wratisl., 1808, A, 8: 43-61.

15. MatusZKIEWICZ J.M., 2007. Zespoły leśne Polski. (Forest communities of Poland). Warszawa, PWN: 358.

16. MiODUSZEWSKI W., 1995. Zasady projektowania, budowy i eksploatacji małych zbiorników wodnych. Metodyczne podstawy rozwoju małej retencji. (Principles of designing, construction and exploitation of small water reservoirs. Methodical bases for the development of small retention). Mater. Inf., 32. Falenty, Wydaw. IMUZ: 104.

17. MiODUSZEWSKI W., 2003. Mała retencja. Ochrona zasobów wodnych i środowiska naturalnego. Poradnik. (Small retention. Protection of water resources and natural environment. A handbook). Falenty, Wydaw. IMUZ: 49.

18. ORŁOWSKI G., 2003. Waloryzacja zadrzewień śródpolnych fragmentu obszaru rolniczego równiny wrocławskiej. (Valorisation of midfield woodlots in a fragment of agricultural area of Wrocław Plain). Acta Sci. Polon., Silv. Colendarum Ratio Industr. Lignaria, 2 (1): 47-58.

19. PeNDER K., RYBAŁtowsKa Z., 1995. Szata roślinna rezerwatu „Las bukowy w Skarszynie”. (Vegetation of the nature reserve „Beech Forest in Skarszyn”). Acta Univ. Wratisl., 1667: 79-99.

20. PuChNiARSKi H.T., 2000. Krajowy program zwiększania lesistości. Poradnik od A do Z. Zalesienia porolne. (Country programme of increasing forest area. A guide from A to Z. Post-farming afforestation). Warszawa, PWRiL: 43-46.

21. ReJMAn J., TURSKi R., PALUSZEK J., 1998. Spatial and temporal variations in erodolility od loess soil. Soil Tollage Res., 46: 61-68.

22. RoJeK M., 1987. Rozkład czasowy i przestrzenny klimatycznych i rolniczo-klimatycznych bilansów wodnych na terenie Polski. (Spatial and temporal distribution of climatic and agro-climatic water balances in Poland). Zesz. Nauk. AR Wroc. Rozpr. 62: 67.

23. SZEWRAŃSKI Sz., ŻMUDA R., KRUKOWSKI M., WAWER R., 2006. Ocena obciążeń antropogenicznych i koncepcja rewaloryzacji cieku w małej zlewni rolniczej. (The assessment of anthropogenic loads and the concept of stream restoration in a small agricultural watershed). Rocz. Gleb., 57, 1/2: 192199.

24. WAwer R., Nowocień E., Podolski B., SzewrańSki Sz., ŻMUda R., 2008. Analiza sieci dróg rolniczych pod kątem ochrony przed erozją wodną powierzchniową. (Analysis of the network of farm roads in view of protection from surface water erosion). Zesz. Probl. Post. Nauk Rol., 526: 257-263.

25. WĘGOREK T., 1997. Znaczenie zadrzewień w przeciwdziałaniu wodnej i wietrznej erozji gleby. W: Znaczenie zadrzewień w krajobrazie rolniczym oraz aktualne problemy rozwoju w przyrodniczogospodarczych warunkach Polski. (The importance of woodlots for counteracting water and aeolian erosion. In: The importance of woodlots in agricultural landscape and present problems of development under natural and economic conditions of Poland). Płock, Urz. Woj.: 28-39.

26. WISZNIEWSKI W., CHEŁCHOWSKI W., 1975. Charakterystyka klimatu i regionalizacja klimatologiczna Polski. (Climate characteristics and climatic regionalisation of Poland). Warszawa, WKiŁ: 37.

27. ZIEMNICKI S., 1968. Melioracje przeciwerozyjne. (Counter-erosion reclamations). Warszawa, PWRiL: 189.

28. ŻARSKA B., 2005. Ochrona krajobrazu. (Landscape protection). Warszawa, Wydaw. SGGW: 252.

29. ŻMUDA R., 2006. Funkcjonowanie systemu transportu fluwialnego w malej zlewni zagrożonej erozją wodna gleb. (Functioning of the fluvial transport system in a small watershed threatened by water erosion of soils). Zesz. Nauk. AR Wroc., 544 Rozpr., 243: 165.

30. ŻMUDA R., SASIK J., SZEWRAŃSKI S., 2001. Próba oceny wpływu zmian użytkowania na wielkość denudacji odpływowej. (An attempt of evaluating the effect of land use changes on the outflow denudation). Folia Univ. Agricult. Stetin., 217 Agricult., 87: 239-242.

31. ŻMUDA R., SASIK J., SZEWRAŃSKI S., 2005. Analiza potrzeb zmian zagospodarowania przestrzennego Wzgórz Trzebnickich w aspekcie ochrony przed erozją wodną gleb. (An analysis of the needs of 
changing spatial management of the Trzebnickie Hills in view of protecting soils from water erosion) Acta Agrophys., 115, 5(1): 229-237.

\section{STRESZCZENIE}

\section{Zmiany w krajobrazie w aspekcie ochrony gleb przed erozją wodną na przykładzie zlewni Mielnicy}

Słowa kluczowe: architektura krajobrazu, erozja wodna gleb, fitomelioracje

Praca dotyczy zagadnień związanych z kształtowaniem krajobrazu terenów erodowanych. Procesy erozyjne, zwłaszcza erozja wodna gleb, degradując środowisko glebowe, wywołują zmiany $w$ istniejących krajobrazach, czyniąc je mniej atrakcyjnymi, a nawet nieprzyjaznymi człowiekowi. To z kolei przemawia za koniecznością wprowadzenia działań ochronnych, m.in. poprzez odpowiednie kształtowanie krajobrazu rolniczego, w celu zmniejszenia negatywnych następstw tych procesów. W pracy przedstawiono koncepcję zabiegów przeciwerozyjnych niezbędnych do wprowadzenia na obszarze Wzgórz Trzebnickich i ich wpływ na krajobraz. Koncepcję tych działań przedstawiono na przykładzie zlewni rolniczej cieku Mielnica. Zwrócono szczególną uwagę na aspekt wizualny krajobrazu, a także na funkcjonowanie jego elementów. Tytułowe zmiany w krajobrazie przedstawiono za pomocą wizualizacji fotograficznych zestawionych ze stanem obecnym zlewni.

Reviewers:

Prof. Krzysztof Maślanka

Prof. Edward Pierzgalski 